Jurnal Ilmu Ilmu Agribisnis: Journal of Agribusiness Science, 9(3), Agustus 2021

\title{
KERAGAAN AGROINDUSTRI KERIPIK SINGKONG DI KECAMATAN GEDONG TATAAN KABUPATEN PESAWARAN
}

\author{
(The Performance of Cassava Chips Agroindustry in Gedong Tataan Subdistrict \\ Pesawaran District)
}

Lea Ayu Utari, Fembriarti Erry Prasmatiwi, Ktut Murniati

Jurusan Agribisnis, Fakultas Pertanian, Universitas Lampung, Jl. Prof. Dr. Soemantri Bojonegoro No.1

Bandar Lampung, 35145, e-mail: fembriarti.erry@fp.unila.ac.id

\begin{abstract}
The purposes of this research were to analyze the performance of cassava chips agroindustry reviewed from procurement of raw materials, labor productivity, production capacity, product quality, delivery speed, flexibility, and added value and income. The research used was a survey method. Research data collection was carried out in March 2019 in Gedong Tataan Subdistrict with the consideration that agro-industries were actively producing continuously and had the potency to be developed. The research locations were in three villages of cassava chips agro-industry centers, namely Karang Anyar Village, Bagelen Village, and Sungai Langka Village. Respondents were 14 cassava chips agro-industries. Raw material procurement, product quality, delivery speed, and flexibility were analyzed qualitatively descriptively. Productivity, production capacity, and income were analyzed quantitatively. Added value is analyzed using the Hayami method. The results showed that the procurement of raw cassava chips was correct in the type and quantity, while it was not correct in place. The average of productivity per month was $41.65 \mathrm{~kg} / \mathrm{HOK}$ and the average of production capacity per month was 79\%. Product quality and delivery speed were good enough, and flexibility was not optimal. The agroindustry had a positive added value, profit with $R / C>1$, and the average of income per month of IDR 7,613,146.29.
\end{abstract}

Key words: agroindustry, cassava chips, performance

\section{PENDAHULUAN}

Industri pengolahan memiliki peran penting dalam pertumbuhan ekonomi Provinsi Lampung. BPS Provinsi Lampung (2018) menyatakan bahwa kontribusi PDRB Provinsi Lampung tertinggi ke dua ditempati oleh sektor industri pengolahan dengan sumbangsih mencapai 18,91 persen. Salah satu bagian dari sektor industri pengolahan yaitu agroindustri. Agroindustri yang sering dijumpai salah satunya yaitu agroindustri yang menggunakan singkong sebagai bahan bakunya.

Singkong di Provinsi Lampung menurut BPS (2016) merupakan sentra produksi terbesar di Indonesia dengan produksi mencapai 7.387.084 ton pada tahun 2015. Produktivitas singkong terus mengalami peningkatan dari tahun 2006 sampai dengan 2015 dengan rata-rata produktivitas sebesar 243,05 kuintal perhektar. Sebagai sentra penghasil singkong terbesar, banyak pelaku agroindustri yang menjadikan singkong sebagai bahan baku utama dalam proses produksi usahanya.

Salah satu kabupaten yang banyak bergerak di bidang agroindustri adalah Kabupaten Pesawaran.
Menurut BPS Provinsi Lampung (2018), Kabupaten Pesawaran menjadi tiga kabupaten dengan kemajuan pembangunan manusia paling cepat yaitu mencapai 1,51 persen. Kemajuan pembangunan di Kabupaten Pesawaran salah satunya ditunjukkan dengan berkembangnya sumbangsih lapangan usaha yang diberikan sektor industri pengolahan dengan sumbangsih mencapai 14,06 persen.

Kabupaten Pesawaran memiliki 11 kecamatan dengan ibukota kecamatan yaitu Gedong Tataan. Menurut BPS Kabupaten Pesawaran (2018), sentra agroindustri Kabupaten Pesawaran terletak di Kecamatan Gedong Tataan. Dinas Perindustrian dan Perdagangan Kabupaten Pesawaran (2018) menyatakan bahwa salah satu potensi Kecamatan Gedong Tataan adalah industri pangan olahan singkong. Olahan singkong unggulan yang dihasilkan Kecamatan Gedong Tataan, salah satunya adalah keripik singkong.

Menurut data UKM Kecamatan Gedong Tataan di Desa Karang Anyar tahun 2017, agroindustri keripik singkong termasuk agroindustri yang cukup banyak diusahakan dengan total pelaku 24 
agroindustri keripik singkong. Namun seiring berjalannya waktu, terjadi penurunan jumlah agroindustri menjadi 11 disebabkan oleh lama berdiri usaha dan permodalan yang kalah saing dengan agroindustri yang telah berdiri lebih dari 3 tahun. Agroindustri berusia lebih dari 3 tahun memiliki link atau langganan pemasok singkong dan konsumen yang lebih banyak dibandingkan agroindustri keripik singkong berusia di bawah 3 tahun. Permasalahan tersebut menyebabkan agroindustri tidak mampu bertahan di saat terjadinya kenaikan harga bahan baku produksi.

Pengadaan bahan baku singkong tergantung kepada musim. Musim hujan dapat menghambat sampainya bahan baku kepada pelaku agroindustri yang berimbas pada penundaan waktu produksi. Pengadaan bahan baku juga tergantung kepada umur panen singkong. Ketidakpastian pengadaan bahan baku singkong menyebabkan ketidakstabilan harga bahan baku, sehingga berpengaruh terhadap pengelolaan modal kerja dan pendanaan, selain itu ketidakpastian pengadaan juga berdampak pada tidak tercapainya target produksi keripik singkong para pelaku agroindustri. Permasalahan lain yang dihadapi yaitu penurunan permintaan yang diakibatkan masuknya musim buah (durian dan rambutan) yang membuat masyarakat mengganti keripik singkong dengan buah-buahan sebagai makanan selingan.

Permasalahan mengenai pengadaan bahan baku juga berkaitan erat dengan keragaan agroindustri keripik singkong. Pengadaan bahan baku yang baik akan menghasilkan keragaan agroindustri yang baik. Semakin baik pengadaan suatu agroindustri, maka akan semakin besar nilai tambah yang diperoleh, yang berimbas kepada peningkatan pendapatan bagi para pelaku agroindustri.

Peningkatan pendapatan dapat meningkatkan kesejahteraan bagi para pelaku agroindustri keripik singkong, sehingga berdasarkan berbagai permasalahan tersebut, maka tujuan penelitian menganalisis keragaan agroindustri yang ditinjau dari pengadaan bahan baku sesuai dengan 6 tepat (tepat waktu, tepat tempat, tepat harga, tepat jenis, tepat kualitas, dan tepat kuantitas), produktivitas tenaga kerja, kapasitas produksi, kualitas produk, kecepatan pengiriman, fleksibilitas, analisis nilai tambah, dan pendapatan agroindustri sebagai bahan evaluasi terhadap peningkatan agroindustri keripik singkong.

\section{METODE PENELITIAN}

Penelitian dilakukan di agroindustri keripik singkong yang berada di Kecamatan Gedong Tataan Kabupaten Pesawaran dengan menggunakan metode survei. Pemilihan lokasi dilakukan secara sengaja (purposive) seperti penelitian Medika, Abidin, dan Kasymir (2016) dan Arsita, Affandi, dan Situmorang (2020), dengan pertimbangan agroindustri keripik singkong aktif berproduksi dan memiliki potensi untuk dikembangkan. Responden dalam penelitian ini adalah para pelaku agroindustri keripik singkong yang berjumlah 14 (empat belas) agroindustri. Agroindustri berada di Desa Karang Anyar, Desa Bagelen, dan Desa Sungai Langka.

Jenis data yang digunakan pada penelitian ini yaitu data primer dan sekunder. Data primer yang dikumpulkan terdiri dari identitas pelaku (pemilik) agroindustri, profil agroindustri, pengadaan bahan baku, dan proses pengolahan keripik singkong. Data sekunder diperoleh melalui instansi, pustaka, serta publikasi yang terkait dengan penelitian.

Metode analisis yang digunakan yaitu metode analisis deskriptif kualitatif dan deskriptif kuantitatif. Analisis yang digunakan untuk pengadaan bahan baku berupa analisis enam tepat menggunakan skor mengacu pada Assauri (1999) yaitu tepat waktu, tepat tempat, tepat harga, tepat jenis, tepat kuantitas, dan tepat kualitas berdasarkan saat keadaan produksi keripik rendah, sedang, dan tinggi. Analisis deskriptif kualitatif ini juga digunakan untuk menganalisis permasalahan atau kendala dalam pengadaan bahan baku.

Analisis yang digunakan untuk keragaan agroindustri ditinjau dan diukur berdasarkan komponen produktivitas tenaga kerja, kapasitas produksi, kualitas produk, kecepatan pengiriman, dan fleksibilitas menurut Prasetya dan Lukiastuti (2009) seperti penelitian Sari, Zakaria, dan Affandi (2015).

1. Produktivitas Tenaga Kerja

Produktivitas adalah ukuran mengkonversi input dari proses transformasi ke dalam output. Pengukuran produktivitas tenaga kerja diukur dengan menggunakan persamaan 1.

Produktivitas $=\frac{\text { Output (kg) }}{\text { Tenaga Kerja }(\mathrm{HOK})} \ldots \ldots \ldots(1)$ 
2. Kapasitas

Kapasitas yaitu ukuran yang menyangkut kemampuan dari output dari suatu proses. Pengukuran kapasitas agroindustri diukur dengan menggunakan persamaan 2 seperti penelitian Safitri, Abidin, dan Rosanti (2014).

Capacity Utilization $=\frac{\text { Actual output }}{\text { Design Capacity }} \ldots . . .(2)$

3. Kualitas

Syarat kualitas keripik singkong mengacu pada syarat SNI keripik singkong (SNI 01-43051996) yang diukur melalui bau, rasa, warna, dan tekstur.

4. Kecepatan Pengiriman

Kecepatan pengiriman yang pertama diukur melalui jumlah waktu antara produk ketika dipesan untuk dikirimkan kepelanggan, ke dua adalah ketepatan waktu dalam pengiriman. Pengukuran pertama mengacu pada Sari, et al. (2015) bahwa untuk mengirimkan produk ke pelanggan yang baik yaitu 30 menit dengan jarak tempuh $5 \mathrm{~km}$. Pengukuran kedua mengacu pada Syarief, Lestari, dan Kasymir (2019) bahwa kecepatan pengiriman dikatakan baik apabila agroindustri melakukan pengiriman sesuai dengan keadaan agroindustri.

5. Fleksibilitas

Fleksibiltas yang pertama diukur denganwaktu yang dibutuhkan dari datangnya bahan baku hingga menjadi keripik singkong yang berkisar antara 0-1 hari. Ke dua yaitu kemampuan bereaksi dalam volume untuk menghasilkan keripik singkong. Dimensi ke dua dapat dikatakan baik jika dengan $2,5 \mathrm{~kg}$ bahan baku singkong menghasilkan $1 \mathrm{~kg}$ keripik singkong. Ke tiga yaitu kemampuan dari proses produksi yang menghasilkan lebih dari satu produk secara serempak atau kemampuan agroindustri mengubah bahan baku singkong menjadi produk selain keripik singkong.

Analisis pendapatan yang dilakukan mengacu pada Soekartawi (2000) seperti penelitian Shafira, Lestari, dan Affandi (2018) dan Pratiwi, Haryono, dan Abidin (2020). Pendapatan merupakan pengurangan dari penerimaan dengan biaya total. Perhitungan pendapatan dirumuskan pada persamaan 3 .

$\pi=\mathrm{TR}-\mathrm{TC}$

$$
\begin{array}{ll}
\pi=\text { Y.Py- } & \sum \text { Xi.Pi-BTT..................... } \\
\text { Keterangan }: & \\
\pi \quad=\text { pendapatan }(\mathrm{Rp}) \\
\text { Py } \quad=\text { harga keripik singkong }(\mathrm{Rp}) \\
\mathrm{X}_{\mathrm{i}} \quad=\text { faktor produksi }(\mathrm{i}=1,2,3, \ldots \ldots, \mathrm{n}) \\
\mathrm{Px}_{\mathrm{i}} \quad=\text { harga faktor produksi ke-i (Rp) } \\
\mathrm{BTT} \quad=\text { biaya tetap total }(\mathrm{Rp})
\end{array}
$$

Setelah perhitungan pendapatan, dilakukan perhitungan $\mathrm{R} / \mathrm{C}$ untuk melihat keuntungan suatu usaha dengan menggunakan persamaan 4.

$\mathrm{R} / \mathrm{C}=\frac{\mathrm{TR}}{\mathrm{TC}}$

Keterangan :

$\mathrm{R} / \mathrm{C}=$ nisbah penerimaan dan biaya

$\mathrm{TR}=$ total revenue atau penerimaan total $(\mathrm{Rp})$

$\mathrm{TC}=$ total cost atau biaya total (Rp)

Kriteria pengambilan keputusan adalah:

a) Jika R/C >1, maka usaha mengalami keuntungan.

b) Jika $\mathrm{R} / \mathrm{C}<1$, maka usaha mengalami kerugian.

c) Jika $\mathrm{R} / \mathrm{C}=1$, maka usaha mengalami impas.

Nilai tambah merupakan pertambahan nilai suatu komoditas, karena mengalami sentuhan proses seperti pengolahan. Analisis nilai tambah yang dilakukan mengacu pada Hayami (1987) dalam penelitian Kemala, Hudoyo, dan Soelaiman (2019) dan Sinaga, Lestari, dan Situmorang (2019). Kriteria nilai tambah (NT) adalah:

a) Jika NT $>0$, maka pengembangan agroindustri memberi nilai tambah yang positif.

b) Jika NT < 0, maka pengembangan agroindustri memberi nilai tambah yang negatif.

\section{HASIL DAN PEMBAHASAN}

\section{Keragaan Agroindustri}

Agroindustri keripik singkong di Kecamatan Gedong Tataan yang diteliti berjumlah 14 agroindustri dengan rata-rata lama berdiri usaha di atas 3 tahun. Para pelaku agroindustri berada di Desa Karang Anyar, Desa Bagelen, dan Desa Sungai Langka. Bahan baku diperoleh melalui pengepul singkong yang berada di Desa Karang Anyar. Pengepul singkong memperoleh singkong dari Lampung Timur. Tenaga kerja yang digunakan adalah tenaga kerja langsung dan tak langsung. Penggunaan tenaga kerja untuk memproduksi keripik rata-rata sebesar 50,48 HOK per bulan dengan upah rata-rata tenaga kerja Rp60.000/produksi.

Agroindustri keripik singkong di Kecamatan Gedong Tataan sejalan dengan penelitian Akbar, Lestari, dan Nugraha (2020) bahwa tenaga kerja berjumlah 1-9 orang berdasarkan Peraturan Menteri Perindustrian No.64/M-IND/PER/7/2016 tergolong skala usaha kecil. Agroindustri 
berdasarkan jumlah target produksi tergolong menjadi skala usaha tinggi, sedang, dan rendah dengan persentase 14,29 persen, 57,14 persen, dan 28,57 persen. Pemasaran dilakukan rata-rata 4 kali dalam satu minggu.

\section{Pengadaan Bahan Baku}

Bahan baku yang digunakan dalam penelitian ini berupa singkong jenis Garuda/IRR. Waktu panen singkong berkisar antara 9-11 bulan. Berdasarkan hal tersebut, pengadaan bahan baku pada agroindustri keripik singkong perlu diperhatikan, dikarenakan umur panen singkong yang akan digunakan dapat mempengaruhi kualitas keripik yang akan dihasilkan. Bahan-bahan penunjang seperti minyak goreng, garam, penyedap rasa, gula pasir, bawang putih, cabai merah, asam, dan plastik kemasan diperoleh dari pasar tradisional dan toko sembako terdekat. Pengolahan keripik singkong menggunakan bahan bakar kayu. Kayu diperoleh dari desa di wilayah Kecamatan Gedong
Tataan. Pengadaan bahan baku pada penelitian ini dilihat berdasarkan tiga keadaan, yaitu saat produksi tinggi, saat produksi sedang, dan saat produksi rendah. Pengadaan bahan baku disajikan pada Tabel 1. Produksi tinggi adalah saat agroindustri berada di puncak maksimal untuk berproduksi (perayaan Idul Fitri, Idul Adha, HUT RI, Natal dan Tahun Baru). Produksi sedang adalah saat agroindustri berproduksi mencapai target harian agroindustri. Produksi rendah adalah saat agroindustri berproduksi di bawah target harian. Produksi rendah disebabkan oleh beberapa hal, yaitu musim hujan yang berpengaruh terhadap keterlambatan pengadaan bahan baku dari waktu pemesanan sampai ke pelaku agroindustri, musim paceklik berupa ketersediaan bahan baku terbatas/ belum musim panen, penurunan permintaan keripik singkong yang disebabkan pemenuhan kebutuhan lainnya, dan persaingan dengan musim buah. Bulan produksi tinggi, sedang, dan rendah disajikan pada Gambar 1.

Tabel1. Pengadaan bahan baku Agroindustri Keripik Singkong di Kecamatan Gedong Tataan, 2019

\begin{tabular}{|c|c|c|c|c|c|c|}
\hline \multirow{2}{*}{ Pengadaan 6 Tepat } & \multicolumn{2}{|c|}{ Produksi Tinggi } & \multicolumn{2}{|c|}{ Produksi Sedang } & \multicolumn{2}{|c|}{ Produksi Rendah } \\
\hline & Agroindustri & $(\%)$ & Agroindustri & $(\%)$ & Agroindustri & $(\%)$ \\
\hline \multicolumn{7}{|c|}{$\begin{array}{l}\text { Tepat Waktu } \\
(0-1 \text { hari bahan baku datang dari waktu } \\
\text { pemesanan) }\end{array}$} \\
\hline Tepat & 10 & 71,43 & 11 & 78,57 & 4 & 28,57 \\
\hline Kurang tepat & 4 & 28,57 & 3 & 21,43 & 8 & 57,14 \\
\hline Tidak tepat & 0 & 0,00 & 0 & 0,00 & 2 & 14,29 \\
\hline \multicolumn{7}{|c|}{$\begin{array}{l}\text { Tepat Tempat } \\
\text { (Mudah dijangkau, letak strategis) }\end{array}$} \\
\hline Tepat & 0 & 0,00 & 0 & 0,00 & 0 & 0,00 \\
\hline Kurang tepat & 0 & 0,00 & 0 & 0,00 & 0 & 0,00 \\
\hline Tidak tepat & 14 & 100,00 & 14 & 100,00 & 14 & 100,00 \\
\hline \multicolumn{7}{|c|}{$\begin{array}{l}\text { Tepat Harga } \\
\text { (Harga bahan baku } \leq \mathrm{Rp} 1.800)\end{array}$} \\
\hline Tepat & 8 & 57,14 & 14 & 100,00 & 0 & 0,00 \\
\hline Kurang tepat & 4 & 28,57 & 0 & 0,00 & 4 & 28,57 \\
\hline Tidak tepat & 2 & 14,29 & 0 & 0,00 & 10 & 71,43 \\
\hline \multicolumn{7}{|l|}{$\begin{array}{l}\text { Tepat Jenis } \\
\text { (Garuda/IRR) }\end{array}$} \\
\hline Tepat & 14 & 100,00 & 14 & 100,00 & 14 & 100,00 \\
\hline Kurang tepat & 0 & 0,00 & 0 & 0,00 & 0 & 0,00 \\
\hline Tidak tepat & 0 & 0,00 & 0 & 0,00 & 0 & 0,00 \\
\hline \multicolumn{7}{|c|}{$\begin{array}{l}\text { Tepat Kualitas } \\
\text { (Tidak kehijauan, daging putih bersih } \\
\text { mengkilat, tekstur halus, daging padat, } \\
\text { ukuran sedang - besar) }\end{array}$} \\
\hline Tepat & 9 & 64,29 & 9 & 64,29 & 5 & 35,71 \\
\hline Kurang tepat & 5 & 35,71 & 5 & 35,71 & 9 & 64,29 \\
\hline Tidak tepat & 0 & 0,00 & 0 & 0,00 & 0 & 0,00 \\
\hline \multicolumn{7}{|c|}{$\begin{array}{l}\text { Tepat Kuantitas } \\
\text { (Jumlah bahan baku yang tersedia untuk } \\
\text { membuat keripik sesuai dengan target } \\
\text { produksi) }\end{array}$} \\
\hline Tepat & 14 & 100,00 & 14 & 100,00 & 7 & 50,00 \\
\hline Kurang tepat & 0 & 0,00 & 0 & 0,00 & 2 & 14,29 \\
\hline Tidak tepat & 0 & 0,00 & 0 & 0,00 & 5 & 35,71 \\
\hline
\end{tabular}


Tabel 1 menunjukkan komponen tepat tempat untuk semua keadaan adalah tidak tepat, dikarenakan lokasi penelitian dengan lokasi sumber bahan baku tidak dekat, yaitu antara Kecamatan Gedong Tataan dengan Kabupaten Lampung Timur. Syarat suatu agroindustri dinyatakan tepat tempat menurut Assauri (1999), salah satunya adalah agroindustri dekat dengan sumber bahan baku. Pengadaan bahan baku 6 tepat saat produksi tinggi dan sedang rata-rata sudah tepat (waktu, harga, jenis, kualitas, dan kuantitas), saat produksi rendah tepat jenis dan kuantitas sudah tepat, tepat waktu dan tepat kualitas kurang tepat, dan tepat harga belum tepat.

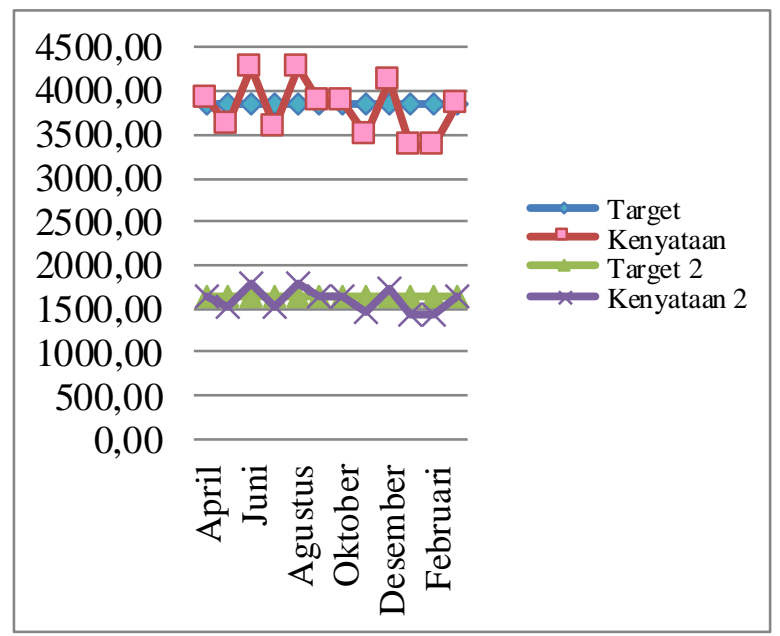

Gambar 1. Penggunaan singkong (garis merah) dan produksi keripik singkong (garis ungu) 2018-2019.

\section{Produktivitas, Kapasitas, Kualitas, Kecepatan Pengiriman, dan Fleksibilitas}

\section{Produktivitas Tenaga Kerja}

Rata-rata output maksimal per 1 bulan penelitian agroindustri keripik singkong sebesar $2.130,44 \mathrm{~kg}$, rata-rata penggunaan TK 54,47 HOK, dan menghasilkan rata-rata produktivitas sebesar 41,65 kg/HOK. Produktivitas tenaga kerja agroindustri keripik singkong lebih besar dibandingkan penelitian Sagala, Affandi, dan Ibnu (2013) tentang agroindustri kelanting dan penelitian Sari, et al. (2015) tentang agroindustri emping melinjo dengan hasil sebesar 16,07 kg/HOK, dan 7,24 kg/HOK.

2. Kapasitas

Rata-rata output per 1 bulan penelitian agroindustri keripik singkong sebesar 1.658,22 $\mathrm{kg}$, dengan rata-rata output maksimal sebesar $2.130,44 \mathrm{~kg}$, dan menghasilkan rata-rata kapasitas agroindustri keripik singkong sebesar
79 persen. Kapasitas produksi agroindustri keripik singkong lebih kecil dibandingkan penelitian Sagala et al. (2013) dan Sari et al. (2015) sebesar 92 persen dan sebesar 84 persen. Kapasitas yang belum maksimal tersebut menurut Sari et al. (2015) dapat dimaksimalkan atau ditingkatkan lagi dengan menambah persediaan bahan baku, meningkatkan kualitas sumber daya manusia, dan penggunaan peralatan yang lebih modern.

3. Kualitas

Agrondustri keripik singkong sudah sesuai dengan standar SNI keripik singkong yaitu berdasarkan bau normal, rasa khas, warna normal, dan tekstur renyah, sejalan dengan penelitian Putri, Haryono, dan Nugraha (2019) bahwa standar mutu agroindustri keripik pisang sudah baik, karena sesuai dengan SNI keripik pisang.

4. Kecepatan Pengiriman

Rata-rata agroindustri keripik singkong, melakukan pengiriman produk rata-rata 4 hari dalam satu minggu. Hasil penelitian sejalan dengan Syarief et al. (2019) bahwa waktu pengiriman produk yang dipesan untuk sampai kepelanggan tidak memerlukan waktu yang banyak dan agroindustri kerupuk bawang mengambil produk lima hari dalam seminggu.

5. Fleksibilitas

Transformasi singkong menjadi keripik singkong memerlukan waktu 0-1 hari. Agroindustri membutuhkan 2,5 kg singkong untuk menghasilkan $1 \mathrm{~kg}$ keripik singkong. Agroindustri keripik singkong keseluruhan belum menghasilkan produk pengolahan yang lain dengan bahan baku yang sama. Aspek fleksibilitas belum optimal, dikarenakan pada pengukuran ketiga belum dapat dilakukan, seperti penelitian Sari et al. (2015) bahwa aspek fleksibilitas agroindustri emping melinjo belum baik, dikarenakan pada tahapan pengukuran ke tiga belum dapat dilakukan.

Menurut Sari et al. (2015) dimensi ke tiga fleksibilitas dapat ditingkatkan dengan cara salah satunya berupa melalui pengembangan inovasi untuk dapat menghasilkan produk lain dari bahan baku yang sama.

\section{Analisis Nilai Tambah}

Hasil analisis nilai tambah produk keripik singkong tawar, gurih, dan pedas disajikan pada Tabel 2. 
Jurnal Ilmu Ilmu Agribisnis: Journal of Agribusiness Science, 9(3), Agustus 2021

Tabel 2. Nilai Tambah Agroindustri Keripik Singkong di Kecamatan Gedong Tataan per Bulan

\begin{tabular}{|c|c|c|c|c|c|}
\hline \multirow{2}{*}{\multicolumn{2}{|c|}{$\begin{array}{l}\text { No. } \quad \text { Variabel } \\
\text { Output, Input dan Harga }\end{array}$}} & \multirow{2}{*}{ Koefisien } & \multicolumn{3}{|c|}{ Keripik Singkong per Bulan } \\
\hline & & & \multirow{2}{*}{$\begin{array}{l}\text { Tawar } \\
176000\end{array}$} & \multirow{2}{*}{$\begin{array}{l}\text { Gurih } \\
1.383,33\end{array}$} & \multirow{2}{*}{$\begin{array}{l}\text { Pedas } \\
1.831,33\end{array}$} \\
\hline 1 & Output (Kg/bulan) & A & & & \\
\hline 2 & Bahan Baku (Kg/bulan) & B & $4.400,00$ & $3.440,00$ & $3.653,33$ \\
\hline 3 & Tenaga Kerja (HOK/bulan) & $\mathrm{C}$ & 49,20 & 39,78 & 74,45 \\
\hline 4 & Faktor Konversi & $\mathrm{D}=\mathrm{A} / \mathrm{B}$ & 0,40 & 0,40 & 0,50 \\
\hline 5 & Koefisien Tenaga Kerja & $\mathrm{E}=\mathrm{C} / \mathrm{B}$ & 0,01 & 0,01 & 0,02 \\
\hline 6 & Harga Output & $\mathrm{F}$ & $11.833,33$ & $13.000,00$ & $15.666,67$ \\
\hline 7 & Upah Rata-rata Tenaga Kerja (Rp/HOK) & $\mathrm{G}$ & $60.000,00$ & $60.000,00$ & $60.000,00$ \\
\hline \multicolumn{6}{|c|}{ Pendapatan dan Keuntungan $(\mathrm{Rp} / \mathrm{Kg})$} \\
\hline 8 & Harga Bahan Baku & $\mathrm{H}$ & $1.779,17$ & $1.812,50$ & $1.813,89$ \\
\hline 9 & Sumbangan Input Lain & I & $1.412,48$ & $1.720,79$ & $2.997,50$ \\
\hline 10 & Nilai Output & $\mathrm{J}=\mathrm{D} \times \mathrm{F}$ & $4.733,33$ & $5.227,71$ & $7.853,35$ \\
\hline \multirow[t]{2}{*}{11} & a. Nilai Tambah & $\mathrm{K}=\mathrm{J}-\mathrm{I}-\mathrm{H}$ & $1.541,69$ & $1.694,42$ & $3.041,96$ \\
\hline & b. Rasio Nilai Tambah & $\mathrm{L}=(\mathrm{K} / \mathrm{J}) \times 100(\%)$ & 32,57 & 32,41 & 38,73 \\
\hline \multirow[t]{2}{*}{12} & a. Imbalan Tenaga Kerja & $M=E \times G$ & 670,91 & 693,85 & $1.222,71$ \\
\hline & b. Bagian Tenaga Kerja & $\mathrm{N}=(\mathrm{M} / \mathrm{K}) \times 100(\%)$ & 43,52 & 40,95 & 40,19 \\
\hline \multirow[t]{2}{*}{13} & a. Keuntungan & $\mathrm{O}=\mathrm{K}-\mathrm{M}$ & 870,78 & $1.000,56$ & $1.819,25$ \\
\hline & b. Tingkat Keuntungan & $\mathrm{P}=\mathrm{O} / \mathrm{K} \times 100(\%)$ & 56,48 & 59,05 & 59,81 \\
\hline \multicolumn{6}{|c|}{ Balas Jasa Pemilik Faktor-faktor Produksi } \\
\hline \multirow[t]{4}{*}{14} & Marjin Keuntungan & $\mathrm{Q}=\mathrm{J}-\mathrm{H}$ & $2.954,17$ & $3.415,21$ & $6.039,46$ \\
\hline & a. Keuntungan & $\mathrm{R}=\mathrm{O} / \mathrm{Q} \times 100 \%$ & 29,48 & 29,30 & 30,12 \\
\hline & b. Tenaga Kerja & $\mathrm{S}=\mathrm{M} / \mathrm{Q} \times 100 \%$ & 22,71 & 20,32 & 20,25 \\
\hline & c. Input lain & $\mathrm{T}=\mathrm{I} / \mathrm{Q} \times 100 \%$ & 47,81 & 50,39 & 49,63 \\
\hline
\end{tabular}

Tabel 2 menunjukkan agroindustri keripik singkong memiliki nilai tambah per 1 bulan penelitian sebesar 32,41-38,73 persen, dengan nilai tambah tertinggi dimiliki oleh agroindustri keripik pedas. Nilai tambah yang dimiliki oleh keripik pedas lebih besar dibandingkan produk lainnya, dikarenakan memiliki bahan tambahan yang lebih banyak dibandingkan tawar dan gurih, khususnya penggunaan cabai. Nilai tambah yang dihasilkan sejalan dengan penelitian Kusuma, Widjaya, dan Situmorang (2020) dan Sagala et al. (2013) yaitu positif atau NT>0 sehingga agroindustri layak untuk dikembangkan.

Tabel 2 juga menunjukkan nilai marjin keuntungan lebih besar dibandingkan dengan nilai tambah, artinya bahwa perhitungan nilai tambah lebih tepat untuk melihat seberapa besar keuntungan yang diperoleh oleh agroindustri. Nilai balas jasa terhadap nilai keuntungan lebih besar dibandingkan dengan nilai tenaga kerja, sehingga agroindustri tergolong padat modal dan memiliki prospek yang baik untuk dijalankan, karena memberikan keuntungan bagi para pelaku agroindustri keripik singkong. Hasil penelitian ini agak sedikit berbeda dengan penelitian Aldhariana, Lestari, dan Ismono (2016) bahwa nilai balas jasa terhadap tenaga kerja lebih besar dibandingkan nilai keuntungan, sehingga memiliki prospek yang baik untuk penyerapan tenaga kerja di sekitar agroindustri beras siger.

\section{Analisis Pendapatan}

Analisis pendapatan disajikan pada Tabel 3 . Analisis pendapatan dihitung berdasarkan jenis produk keripik singkong dan kemudian penarikan kesimpulan berdasarkan rata-rata dari hasil pendapatan ketiga jenis produk keripik singkong (tawar, gurih, dan pedas). Tabel 3 menunjukkan pendapatan atas biaya total tertinggi dimiliki oleh agroindustri keripik pedas dengan pendapatan sebesar Rp10.484.492,58. R/C tertinggi dihasilkan oleh agroindustri keripik pedas dengan nilai $\mathrm{R} / \mathrm{C}$ atas biaya tunai sebesar 1,59 dan $\mathrm{R} / \mathrm{C}$ atas biaya total sebesar 1,57.

Pendapatan dan penerimaan tertinggi dimiliki oleh agroindustri keripik pedas, dikarenakan terdapat bahan tambahan yang lebih banyak dibandingkan produk keripik tawar dan gurih, sehingga menghasilkan nilai tambah yang berpengaruh terhadap pendapatan agroindustri keripik singkong pedas. Rata-rata pendapatan untuk keseluruhan produk yang dihasilkan diperoleh Rp7.613.146,29 dan rata-rata $\mathrm{R} / \mathrm{C}$ atas biaya total sebesar 1,50. Pendapatan agroindustri keripik singkong menguntungkan dengan nilai $\mathrm{R} / \mathrm{C}>1$. Penelitian ini sejalan dengan Syarief et al. (2019) dan Anggraeni, Lestari, dan Indriyani (2017) dengan hasil $\mathrm{R} / \mathrm{C}$ sebesar 1,62 dan R/C 1,04 sehingga usaha mengalami keuntungan. 
Jurnal Ilmu Ilmu Agribisnis: Journal of Agribusiness Science, 9(3), Agustus 2021

Tabel 3. Pendapatan Agroindustri Keripik Singkong di Kecamatan Gedong Tataan per Bulan

\begin{tabular}{|c|c|c|c|c|c|}
\hline \multirow{3}{*}{ No } & \multirow{3}{*}{ Uraian } & \multirow{3}{*}{ Satuan } & \multicolumn{3}{|c|}{ Per Bulan } \\
\hline & & & Tawar & Gurih & Pedas \\
\hline & & & Nilai (Rp) & Nilai (Rp) & Nilai $(\mathrm{Rp})$ \\
\hline \multirow[t]{2}{*}{1} & Penerimaan & & & & \\
\hline & Produksi & $\mathrm{Kg}$ & $20.826 .666,67$ & $17.983 .333,33$ & $28.690 .888,89$ \\
\hline \multirow[t]{30}{*}{2} & Biaya Produksi & & & & \\
\hline & I. Biaya Tunai & & & & \\
\hline & Biaya Variabel & & & & \\
\hline & Singkong & $\mathrm{Kg}$ & 7.828.333,33 & $6.235 .000,00$ & $6.626 .740,74$ \\
\hline & Minyak Goreng & $\mathrm{Kg}$ & $4.693 .333,33$ & $4.171 .428,57$ & $4.457 .142,86$ \\
\hline & Kayu Bakar & Kubik & $888.888,89$ & $903.571,43$ & $1.180 .317,46$ \\
\hline & Garam & Bks & - & $14.000,00$ & $136.000,00$ \\
\hline & Penyedap Rasa & Blek/Bks & - & $400.000,00$ & $118.333,33$ \\
\hline & Gula Pasir & $\mathrm{Kg}$ & - & - & $880.000,00$ \\
\hline & Bawang Putih & $\mathrm{Kg}$ & - & - & $66.666,67$ \\
\hline & Cabai Merah & $\mathrm{Kg}$ & - & - & $2.160 .000,00$ \\
\hline & Asam & $\mathrm{Bks} / \mathrm{Kg}$ & - & - & $201.000,00$ \\
\hline & Plastik & Lembar & $256.666,67$ & $242.666,67$ & $220.000,00$ \\
\hline & Plastik Kemasan & $\mathrm{Kg}$ & - & - & $1.680 .000,00$ \\
\hline & Solar & Liter & $4.000,00$ & $7.392,86$ & $1.721,94$ \\
\hline & Bensin & Liter & $42.666,67$ & - & - \\
\hline & TKL & $\mathrm{HOK}$ & $60.750,00$ & $12.595,24$ & $226.809,52$ \\
\hline & Biaya Listrik & $\mathrm{Rp}$ & $27.500,00$ & $19.880,95$ & $16.904,76$ \\
\hline & Biaya Angkut & $\mathrm{Rp}$ & $89.166,67$ & $49.761,90$ & $93.809,52$ \\
\hline & Total BiayaTunai & $\mathrm{Rp}$ & $13.891 .305,56$ & $12.056 .297,62$ & $18.065 .446,81$ \\
\hline & II. Biaya Diperhitungkan & & & & \\
\hline & Biaya Variabel & & & & \\
\hline & TKTL & HOK & $123.750,00$ & $136.583,33$ & $84.333,33$ \\
\hline & Biaya Tetap & & & & \\
\hline & Penyusutan & $\mathrm{Rp}$ & $108.609,72$ & $108.507,49$ & $86.616,17$ \\
\hline & Total Biaya Diperhitungkan & $\mathrm{Rp}$ & $232.359,72$ & $245.090,82$ & $170.949,50$ \\
\hline & Total Biaya & $\mathrm{Rp}$ & $14.123 .665,28$ & $12.301 .388,44$ & $18.236 .396,31$ \\
\hline & Pendapatan & & & & \\
\hline & Pendapatan Atas Biaya Tunai & $\mathrm{Rp}$ & $6.935 .361,11$ & $5.927 .035,71$ & $10.625 .442,08$ \\
\hline & Pendapatan Atas Biaya Total & $\mathrm{Rp}$ & $6.703 .001,39$ & $5.681 .944,89$ & $10.454 .492,58$ \\
\hline \multirow[t]{3}{*}{3} & $\mathrm{R} / \mathrm{C}$ & & & & \\
\hline & R/C Atas Biaya Tunai & & 1,50 & 1,49 & 1,59 \\
\hline & R/C Atas Biaya Total & & 1,47 & 1,46 & 1,57 \\
\hline
\end{tabular}

\section{KESIMPULAN}

Pengadaan bahan baku keripik singkong sudah tepat (jenis dan kuantitas), sedangkan tidak tepat untuk tempat. Keragaan agroindustri keripik singkong pada indikator fleksibilitas belum dapat dikatakan baik, dikarenakan fleksibilitas agroindustri keripik singkong belum optimal. Nilai tambah terbesar dimiliki oleh agroindustri keripik pedas dan bernilai positif, sehingga agroindustri keripik singkong layak untuk diusahakan. Pendapatan rata-rata sebesar Rp7.613.146,29 dan R/C >1 menandakan usaha mengalami keuntungan.

\section{DAFTAR PUSTAKA}

Akbar TR, Lestari DAH, dan Nugraha A. 2020. Analisis bauran pemasaran, risiko, dan kinerja keuangan agroindustri kopi bubuk cap obor mas Lampung di Kecamatan Kotabumi Kota Kabupaten Lampung Utara. Jurnal Ilmu Ilmu
Agribisnis,

8(1): 77-84. http://jurnal.fp.unila.ac.id/index.php/JIA/articl e/view/4092/2979. [15 Juli 2020].

Aldhariana SF, Lestari DAH, dan Ismono RH. 2016. Analisis keragaan agroindustri beras siger studi kasus pada Agroindustri Toga Sari Kabupaten Tulang Bawang dan Agroindustri Mekar Sari Kota Metro. Jurnal Ilmu Ilmu Agribisnis, $\quad$ 4(3): 317-325. http://jurnal.fp.unila.ac.id/index.php/JIA/articl e/view/1507/1361. [7 Juli 2020].

Anggraeni TS, Lestari DAH, dan Indriani Y. 2017. Keragaan agroindustri tempe, manfaat ekonomi koperasi, dan tingkat partisipasinya sebagai anggota Primkopti Kabupaten Pesawaran. Jurnal Ilmu Ilmu Agribisnis, 5(3):275282.http://jurnal.fp.unila.ac.id/index. php/JIA/article/view/1640/1466. [7 Juli 2020]. Arsita M, Affandi MI, dan Situmorang S. 2020. Kinerja produksi dan nilai tambah agroindustri jamu bubuk di Desa Astro Mulyo Kecamatan Punggur Kabupaten Lampung 
Jurnal Ilmu Ilmu Agribisnis: Journal of Agribusiness Science, 9(3), Agustus 2021

Tengah. Jurnal Ilmu Ilmu Agribisnis, 8(2): 234-241. http://jurnal.fp. unila.ac.id/index.php/JIA/article/view/4058/2 954. [7 September 2020].

Assauri S. 1999. Manajemen Produksi dan Operasi, Edisi Revisi. LPFE-UI. Jakarta.

BPS [Badan Pusat Statistik]. 2016. Produktivitas Ubi Kayu Menurut Provinsi (kuintal/ha) 1993-2015. https://bps.go.id. [27 November]

BPS [Badan Pusat Statistik] Provinsi Lampung. 2018. Produk Domestik Regional Bruto Provinsi Lampung Menurut Lapangan Usaha. https://lampung.bps.go.id. [27 November 2018].

BPS [Badan Pusat Statistik] Kabupaten Pesawaran. 2018. Produk Domestik Regional Bruto Kabupaten Pesawaran Menurut Lapangan Usaha. https://lampung.bps.go.id. [27 November 2018].

Dinas Perindustrian dan Perdagangan Kabupaten Pesawaran. 2018. Klasifikasi Usaha Industri Berdasarkan Peraturan Menteri Perindustrian No. 64/M-IND/PER/7/2016. Dinas Perindustrian dan Perdagangan Kabupaten Pesawaran. Gedong Tataan.

Kantor Desa Karang Anyar. 2018. Data UKM Desa Karang Anyar. Kantor Desa Karang Anyar. Gedong Tataan.

Kemala VP, Hudoyo A, dan Soelaiman A. 2019. Analisis usaha, nilai tambah dan kesempatan kerja agroindustri tempe di Kota Bandar Lampung. Jurnal Ilmu Ilmu Agribisnis, 7(3): 361-367.http://jurnal.I

fp.unila.ac.id/index.php/JIA/article/view/3774 /2775. [7 September 2020].

Kusuma EW, Widjaya S, dan Situmorang S. 2020. Analisis pengadaan bahan baku dan nilai tambah agroindustri keripik ubi kayu di Kecamatan Way Jepara Kabupaten Lampung Timur. Jurnal Ilmu Ilmu Agribisnis, 8(1): 7077.http://jurnal.fp.unila.ac.id/index.php/JIA/ar ticle/view/4339/3116. [7 September 2020].

Medika C, Abidin Z, dan Kasymir E. 2016. Dampak el nino terhadap produksi dan pendapatan agroindustri berbasis singkong di Desa Karang Anyar Kecamatan Gedong Tataan Kabupaten Pesawaran. Jurnal Ilmu Ilmu Agribisnis, 4(4): 351-358. http://jurnal.fp.unila.ac.id/index.php/JIA/ article/view/1516/1370. [7 September 2020].

Prasetya H dan Lukiastuti F. 2009. Manajemen Operasi. Media Pressindo. Jakarta.

Pratiwi O, Haryono D, dan Abidin Z. 2020. Pendapatan dan risiko usahatani ubi kayu di Desa Bumi Agung Marga Kecamatan Abung Timur Kabupaten Lampung Utara. Jurnal
Ilmu Ilmu Agribisnis, 8(1): 9-14. http://jurnal.fp.unila.ac.id/index.php/JIA/articl e/view/4336/pdf. [7 September 2020].

Putri RM, Haryono D, dan Nugraha A. 2019. Analisis kinerja dan lingkungan eksternal internal agroindustri keripik pisang (studi kasus di Desa Sungai Langka Kabupaten Pesawaran). Jurnal Ilmu Ilmu Agribisnis, 7(2):203-210.

http://jurnal.fp.unila.ac.id/index.php/JIA/articl e/view/3382/2583. [7 Juli 2020].

Sagala IC, Affandi MI, dan Ibnu M. 2013. Kinerja usaha agroindustri kelanting di Desa Karang Anyar Kecamatan Gedong Tataan Kabupaten Pesawaran. Jurnal Ilmu Ilmu Agribisnis, 1(1): 60-65. http://jurnal.fp.unila.ac.id/index.php/JIA/articl e/view/132/136. [7 Juli 2020].

Sari IRM, Zakaria WA, dan Affandi MI. 2015. Kinerja produksi, nilai tambah, dan strategi pengembangan agroindustri emping melinjo di Kota Bandar Lampung. Jurnal Ilmu Ilmu Agribisnis, $\quad 3(1)$ : 18-25. http://jurnal.fp.unila.ac.id/index.php/JIA/articl e/view/1013/918. [7 Juli 2020].

Safitri Y, Abidin Z, dan Rosanti N. 2014. Kinerja dan nilai tambah agroindustri sabut kelapa pada Kawasan Usaha Agroindustri Terpadu (KUAT) di Kecamatan Pesisir Selatan Kabupaten Pesisir Barat. Jurnal Ilmu Ilmu Agribisnis, 2

(2):166-173. http://jurnal.fp.unila.ac.id/index.php/JIA/articl e/view/740/681. [7 Juli 2020].

Shafira F, Lestari DAH, dan Affandi MI. 2018. Analisis keragaan agroindustri tahu kulit di Kelurahan Gunung Sulah Kecamatan Way Halim Kota Bandar Lampung. Jurnal Ilmu Ilmu Agribisnis, 6(3): 279-287. http://jurnal.fp.unila.ac.id/index.php/JIA /article/view/3025/2414. [7 Juli 2020].

Sinaga YJ, Lestari DAH, dan Situmorang S. 2019. Keragaan agroindustri mi basah di Kota Bandar Lampung dan perilaku konsumen dalam perspektif diversifikasi pangan. Jurnal Ilmu Ilmu Agribisnis, 7(3): 338-345. http://jurnal.fp.unila.ac.id/index.php/JIA/articl e/view/3025/2414. [15Juli 2020].

Soekartawi. 2000. Pengantar Agroindustri. PT. Raja Grafindo Persada. Jakarta

Syarief ANL, Lestari DAH, dan Kasymir E. 2019. Analisis keragaan Agroindustri Kerupuk Bawang Winda Putri di Kecamatan Tanjung Senang Kota Bandar Lampung. Jurnal Ilmu Ilmu Agribisnis 7(3): 298-305. http://jurnal.fp.unila.ac.id/index. php/JIA/article/view/3766/2767. [7 Juli 2020]. 